\title{
INFRARED THERMOGRAPHY IN CIVIL ENGINEERING: FROM NON DESTRUCTIVE TESTING IN LABORATORY TO OUTDOOR THERMAL MONITORING
}

\author{
Jean Dumoulin ${ }^{1,2+*}$ \\ ${ }^{1}$ IFSTTAR, COSYS/SII, Route de Bouaye, CS4, F-44344, Bouguenais, France \\ ${ }^{2}$ Inria, I4S Team, Campus de Beaulieu, F-35042 Rennes, France \\ +*Presenting and Corresponding Author: jean.dumoulin@ifsttar.fr or jean.dumoulin@inria.fr
}

\begin{abstract}
Being able to perform full field easily noninvasive diagnostics for surveillance and monitoring of transport infrastructures and structures is a major preoccupation of many technical offices. Among all the existing electromagnetic methods, active infrared thermography [1] up to long-term thermal monitoring using uncooled infrared cameras is a promising technique [2].

Anyway, except for vision applications [3], there is few results available in literature (mainly on buildings) for outdoor measurements by infrared thermography. So, to complete, a review of specificities and constraints for in situ measurements on large scale structures is proposed. Key points identified are analyzed versus infrared system technological potential solutions available on the shelf or at laboratory level.

To introduce transfer from laboratory conditions to real field, we will lean on some laboratory works on active thermography applied to quality control of reinforcement operations by gluing composite (CFRP) plates or tissues on concrete structure [4] or voids in pavement [5]. First, we will introduce and discuss the benefit of using numerical heat transfer modeling to optimize the control process [6,7] or generate virtual thermal image sequences to test post-processing methods [8_9]. It will be followed by presentation and discussion on experiments carried out using laboratory specimen. Then, some post-processing analysis approaches will be discussed. Finally, considerations on requirements to move from laboratory conditions to real site field measurements will be proposed.

Following the laboratory level presentation, a review of various experiments carried out, with an adapted infrared system, on different transport infrastructures or large scale element of Civil Engineering structures in outdoor conditions is given [10,11]. Raw results analysis is proposed. Processed data, obtained from few thermal images [12] to few days of experiments [10-11,13] up to several month of experiments, are presented and discussed. Lessons learned from in situ outdoor experiments are then addressed. In particular, field expertise acquired was used to initiate the development of a new infrared system architecture "Cloud2IR" dedicated to long term monitoring [14]. An overview of this new architecture is proposed and discussed. In particular, benefit of using standards for measured data, but not only, is addressed.

Finally, a summary of results obtained and current limitations of studied solutions [15] is given. Perspectives in term of in-situ inspection solutions by active infrared thermography (i.e. under natural solicitations) or by coupling techniques [16] are proposed.
\end{abstract}

KEYWORDS: Active Infrared Thermography, Long term thermal monitoring, Ultra Time Domain, Civil Engineering, Finite Element Modeling, Signal and Image processing, Inverse model 


\section{REFERENCES}

[1] X. Maldague, Theory and practice of infrared technology for non-destructive testing, John Wiley \& sons Inc., 2001.

[2] http://cordis.europa.eu/project/rcn/92241_en.html ISTIMES FP7 project summary and links to open access publications

[3] http://nr2c.fehrl.org/ NR2C FP6 project summary i.e. New Road Construction Concepts: vision 2040

[4] A. Crinière, J. Dumoulin, C. Ibarra-Castanedo and X. Maldague ," Inverse model for defect characterization of externally glued CFRP on reinforced concrete structures: Comparative study of square pulsed and pulsed thermography ", Quantitative InfraRed Thermography Journal, Taylor \& Francis Editor, vol 11, pp 84-114, 2014. DOI: 10.1080/17686733.2014.897512.

[5] J. Dumoulin, L. Ibos, C. Ibarra-Castanedo, A Mazioud, M. Marchetti, X. Maldague and A. Bendada, « Active infrared thermography applied to defect detection and characterization on asphalt pavement samples: comparison between experiments and numerical simulations », Journal of Modern Optics, Special Issue on Advanced Infrared Technology and Applications, Volume 57, Issue 18, October 2010 , pages 1759 - 1769, doi:10.1080/09500340.2010.522738.

[6] A. Crinière, J. Dumoulin, L. Perez, F. Bourquin, "Study of an optimal heating duration indicator for square pulsed thermography applied to CFRP gluing quality control“, First QIRT ASIA conference (Quantitative Infrared Thermography), Mahabalipuram, 6-10 July 2015, India.

[7] L-D. Theroux, J. Dumoulin and E. Merliot, "Automatic installation of thermoplastic CFRP monitored by infrared thermography for pipelines", AITA 2015 (13th International Workshop on Advanced Infrared Thermography and Applications), Pisa, Italy, 29 septembre - 2 October 2015

[8] L-D. Théroux, J. Dumoulin and X. Maldague ," Square heating applied to shearography and active infrared thermography measurements coupling: from feasibility test in laboratory to numerical study of pultruded CFRP plates glued on concrete specimen “,Strain journal, Wiley editor, 2014. doi:10.1111/str.12086.

[9] F. Taillade, M. Quiertant, K. Benzarti, J. Dumoulin, Ch. Aubagnac, Chapter 9: "Nondestructive Evaluation of FRP Strengthening Systems Bonded on Concrete Structures using Pulsed Stimulated Infrared Thermography “, pp 193-208, Book title "Infrared Thermography”, Editeur Raghu V. Prakash, ISBN 978-953-51-0242-7, Intech, open access at the following address http://www.intechopen.com/books/editor/infrared-thermography, mars 2012.

[10] J. Dumoulin, A. Crinière, R. Averty, "Detection and thermal characterization of the inner structure of the "Musmeci" bridge deck by infrared thermography monitoring",Journal of Geophysics and Engineering, Volume 10, Number 2, 17 pages ,November 2013, IOP Science, doi:10.1088/1742-2132/10/6/064003.

[11] J Dumoulin and V Boucher; "Infrared thermography system for transport infrastructures survey with inline local atmospheric parameter measurements and offline model for radiation attenuation evaluations," J. Appl. Remote Sens., 8(1), 084978 (2014). doi:10.1117/1.JRS.8.084978.

[12] ASTM D 4788-03, 2013] Standard test method for detecting delaminations in bridge decks using infrared thermography, 2013

[13] G. A. Washer and P. A. Fuchs, Developments in the Use of Infrared Thermography for the Condition Assessment of Concrete, International Symposium Non-Destructive Testing in Civil Engineering (NDT-CE), September 15 - 17, 2015 , Berlin, Germany

[14] A. Crinière, J. Dumoulin, L. Mevel, G. Andrade Barroso, "Cloud2IR an infrared and environmental SHM information system“, 13th Quantitative Infrared Thermography Conference QIRT2016, 4-8 July 2016, Gdansk, Poland.

[15] J. Dumoulin et A. Crinière, Infrared thermography applied to transport infrastructures monitoring : outcomes and perspectives, in Proc. of SPIE, vol. 10214, Conference Thermosense XXXIX, Anaheim, USA, 9-13 Avril 2017, doi: $10.1117 / 12.2262809$

[16] N. Le Touz, J Dumoulin, G. Genarelli and V Boucher; "Infrared thermography system for transport infrastructures survey with inline local atmospheric parameter measurements and offline model for radiation attenuation evaluations," J. Appl. Remote Sens., 8(1), 084978 (2014). doi:10.1117/1.JRS.8.084978. 